\title{
Quantitative Analysis in (33) Traces Metals in Human Gallstones by ICP-AES
}

\author{
Lazeeza Sattar Omer \\ Department Of Pharmaceutical Chemistry, College Of Pharmacy \\ Hawler Medical University, Erbil, Kurdistan, Iraq \\ Tel: 964-750-488-5717_E-mail: analchem09@yahoo.com
}

Received: December 13, 2010 Accepted: January 11, 2011 doi:10.5539/ijc.v3n2p105

\begin{abstract}
Inductively Coupled Plasma- Atomic Emission Spectroscopy(ICP-AES) was used to analyze human gallstones in $\mathrm{Ag}, \mathrm{Al}, \mathrm{As}, \mathrm{Ba}, \mathrm{Be}, \mathrm{Bi}, \mathrm{Ca}, \mathrm{Cd}, \mathrm{Co}, \mathrm{Cr}, \mathrm{Cu}, \mathrm{Fe}, \mathrm{Ga}, \mathrm{K}, \mathrm{La}, \mathrm{Mg}, \mathrm{Mn}, \mathrm{Mo}, \mathrm{Hg}, \mathrm{Na}, \mathrm{Ni}, \mathrm{P}, \mathrm{Pb}, \mathrm{Sb}, \mathrm{Sc}, \mathrm{Sr}, \mathrm{Th}, \mathrm{Ti}$, $\mathrm{Tl}, \mathrm{U}, \mathrm{V}, \mathrm{W}$, and $\mathrm{Zn}$ ).Thirty gallstones were collected during surgery from patients with cholesterol, pigment and mixed stones. The results of quantitative elemental analysis revealed that, out of 34 elements, 18 elements $\mathrm{Ba}$, $\mathrm{Be}, \mathrm{Bi}, \mathrm{B}, \mathrm{Cd}, \mathrm{Co}, \mathrm{Ga}, \mathrm{La}, \mathrm{Mn}, \mathrm{Mo}, \mathrm{Ni}, \mathrm{Sc}, \mathrm{Th}, \mathrm{Ti}, \mathrm{Tl}, \mathrm{U}, \mathrm{V}$, and $\mathrm{W}$ were not observed in any of the stones. While the concentration of other elements were in the following order $>\mathrm{Ca}>\mathrm{Cu}>\mathrm{Mn}>\mathrm{Sr}>\mathrm{Zn}>\mathrm{Na}>\mathrm{Mg}>\mathrm{Pb}>\mathrm{Fe} \approx \mathrm{A}$ $1 \approx \mathrm{K} \approx \mathrm{Hg}>\mathrm{Sb}>\mathrm{As} \approx \mathrm{Ag} \approx \mathrm{Cr}$. Trace metal concentration in patients from Erbil governorate gallstone were compare with that obtained from patients from other countries.
\end{abstract}

Keywords: Gallstones, ICP-AES, Trace metals, Heavy metals, Cholesterol stones, Pigment stones, Mixed stones

\section{Introduction}

Some metals are naturally present in the human body and are essential to human health. Over 40 elements in the periodic table have biological functions on the human body and health if taken during eating, drinking, or breathing. Many of these elements occur at highly variable concentrations ranging from very low to high. Heavy metals are considered as traces with a density at least five times that of water (Pouls, M, \& Payne, M. 2006 and Iyad A. 2007).

In order to determine the mechanism for the formation of each of these gallstones, more information is required about their respective trace elements and structures.

Gallstone formation is predominant in all countries. Gallstone disease, represents a national health care problem, resulting in more than 600,000 cholecystomies per year (SSAT patient care guidelines 2004) Despite decades of researches, the mechanism of gallstone formation remains incompletely understood. The trace elements are believed to play an important role in gallstone formation (Ashk M. et al, 2003, Rautray T. et al 2006). Un fortunately, the study on this issue is still rather limited.

ICP-AES is one of the most versatile and sensitive analytical techniques for determination of trace elements in both biological and medical fields. (Bianchi F et al 2007).

Flame atomic absorption spectrometry (Xu X. 2002) was used to determine gallstones in inorganic element content, $\mathrm{Mg}, \mathrm{K}, \mathrm{Cu}, \mathrm{Zn}$. They found that the method was simple, fast, needs less samples, less reagent consumption and economic. An analytical digestion method for trace metal determination of trace metal $(\mathrm{Co}, \mathrm{Cr}$, $\mathrm{Cu}, \mathrm{Fe}, \mathrm{Mn}, \mathrm{Ni} \& \mathrm{Zn}$ ) using focused - microwave wet digestion by ICP-AES technique(Sahuquill O. et al 2000). Salimi et al (2003) used proton induced $\mathrm{x}$-ray emission(PIXE) as a sensitive technique to trace elemental analysis of human gallstones.

The present study was undertaken to investigate the structural composition of (33)trace metals in gallstones using ICP-AES method. Also to compare the trace element concentration in the present study with that obtained by other researchers.

\section{Materials and Method}

Gallstones were collected from 30 patients submitted to Rizgary teaching hospital in Erbil, Kurdistan. All the patients were from the same geographical area, 27 females ( age range from 25 to 70 years ) and 3 males (age 60 
years ). All gallstones removed during surgery and washed carefully with distilled water and dried then were powdered in a mortar and pestle. The studied gallstones were classified, in our previous work (Kafia M. et al $2008)^{9}$ into three classes based upon their Fourier transform infrared spectroscopy (FT-IR), into, cholesterol, pigment, and mixed stones.

Gallstone trace metal analysis was quantitated by Inductively Coupled Plasma Atomic Emission Spectroscopy (ICP-AES, ME-ICP 41) (Selvaraju R. et al 2006 and Xu X. 2002) using aqua regia digestion for analysis of 35 trace metals. The trace metal analysis was done in ALS laboratories of analytical chemistry and testing services (Spain).

ICP-AES has been extensively used in the analysis of trace metals in biological material because of its high sensitivity, accuracy, low matrix effect and simpler operation (Bianchi F. et al 2007).

Thirty gallstone of different types, including cholesterol, pigment and mixed stones were washed several times with deionized water until it become free from blood debries and remnants of organic matter (Evenson M. \& Warren B.1975). Each sample was cleaned and then dried at $100^{\circ} \mathrm{C}$ over night, the samples were crushed and ground in agate mortar. The resulting powder was homogenized and then sent to laboratory to find the amount of each studied metal included in the stone content.

\section{Results}

According to our previously published work (Kafia M. et al 2008) the composition of the collection of gallstones extracted from 30 patients living in Erbil revealed that the studied stones are composed mainly of cholesterol. Three stone samples were discovered, which were composed of the cholesterol, pigment and mixed stones. The presence of different trace metals in the stones has been studied. Quantitative chemical analysis of 30 gallstone were done using ICP-AES. The elemental concentration of Ag, Al, As, $\mathrm{Ba}, \mathrm{Be}, \mathrm{Bi}, \mathrm{Ca}, \mathrm{Cd}, \mathrm{Co}, \mathrm{Cr}, \mathrm{Cu}, \mathrm{Fe}, \mathrm{Ga}, \mathrm{K}$, $\mathrm{La}, \mathrm{Mg}, \mathrm{Mn}, \mathrm{Mo}, \mathrm{Na}, \mathrm{Ni}, \mathrm{P}, \mathrm{Pb}, \mathrm{Sb}, \mathrm{Sc}, \mathrm{Sr}, \mathrm{Th}, \mathrm{Ti}, \mathrm{Tl}, \mathrm{U}, \mathrm{V}, \mathrm{W}$, and $\mathrm{Zn}$ were determined and tabulated in table 1. The results of the quantitative elemental analysis revealed that out of 34 elements, 18 elements (B a, Be, Bi, B, C d, Co, G a, La, Mn, Mo, Hg, Ni, Sc, Th, Ti, Tl, U, V, and W) were not present (or at Very low concentration) in any of the stones. The results in table 1 can also be represented generally as the following sequence illustrating the concentration level of the elements in gallstones: $\mathrm{P}>\mathrm{Ca}>\mathrm{Cu}>\mathrm{Mn}>\mathrm{Sr}>\mathrm{Zn}>\mathrm{Na}>\mathrm{Mg}>\mathrm{Pb}>\mathrm{Fe} \approx \mathrm{Al} \approx \mathrm{K} \approx \mathrm{Hg}>$ $\mathrm{Sb}>\mathrm{As} \approx \mathrm{Ag} \approx \mathrm{Cr}$.

Quantitative analysis of cholesterol stones (Group 1)

The results of quantitative micro elemental analysis showed that the elemental concentration following the sequence: $\mathrm{Ca}>\mathrm{Na}>\mathrm{Cu}>\mathrm{Cr}>\mathrm{Al} \approx \mathrm{Ag} \approx \mathrm{Hg} \approx \mathrm{Pb} \approx \mathrm{Sb} \approx \mathrm{Zn}$. It has been found that these gallstones contain mainly $\mathrm{P}$, ranged 30-560 ppm, and it was considered as the main constituent of cholesterol gallstones.

Quantitative analysis of pigment stone (Group 2)

The main characteristic feature of pigment stones is that the elemental concentration of all the studied elements in pigment stones were higher than in other two types of stones (cholesterol and mixed stones). Phosphorous was also considered the main constituent of pigment stone with an average value of more than $10000 \mathrm{ppm}$ (table 1). The element concentration in pigment stones can be ranged in the following order: $\mathrm{Cu}>\mathrm{Mn}>\mathrm{Zn}>\mathrm{Ca}>\mathrm{Sr}>\mathrm{Pb}>$ $\mathrm{Na}>\mathrm{Ag}>\mathrm{As}>\mathrm{Fe}>\mathrm{K}>\mathrm{Al}>\mathrm{Cr} \approx \mathrm{Hg}$.

Quantitative analysis of mixed stones (Group3)

As in other types of gallstone, the main constituent of mixed stones is phosphorous and its concentration range is found from 750 to $2770 \mathrm{ppm}$. While the concentration of other elements were in the following order:

$\mathrm{Ca}>\mathrm{Cu}>\mathrm{Mn}>\mathrm{Sr}>\mathrm{Zn}>\mathrm{Na}>\mathrm{Mg}>\mathrm{Pb}>\mathrm{Fe} \approx \mathrm{Al} \approx \mathrm{K} \approx \mathrm{Hg}>\mathrm{Sb}>\mathrm{As} \approx \mathrm{Ag} \approx \mathrm{Cr}$.

\section{Discussion}

According to our experimental results several gallstones were distinguished as were sharply differing in the composition from the average element concentration in the samples.

It has been found that these gallstones contain mostly calcium as cation, and was considered as the main constituent of stones of all different types (Golovanova 2006). It is obvious that Ca content is affected by the type of food and drinks patient take, including diary and milk products, eggs, tea, and hard water (Iyad A. 2007). A strong relationship was found between the Ca content in drinking water in Erbil and that in gallstones of the patients from the same location (Kafia $\mathrm{M}$ et al 2009). This indicates that the main source of $\mathrm{Ca}$ comes from the water that people drink (Aboud I. 2006). Concentration of transition metal ions such as $\mathrm{Cu}, \mathrm{Mn}, \& \mathrm{Zn}$ were high. The presence of $\mathrm{Cu}$ ions range between 2 to 238 . Green foods, flour, milk products and meats were mainly 
responsible for these high concentrations. $\mathrm{Mn}$ is present in pigment and mixed gallstones ranging between 16-1350 ppm. The main source of $\mathrm{Mn}$ is beans, tea, and green foods. Alkali metals ( $\mathrm{Na}, \mathrm{K}, \mathrm{Sr}$ ) are present in low concentration. Our results were in agreement with those reported by Al- Sibaai A. et al (2006). The main contributor for these metals is their presence in drinking water, and the food is another source of these elements (Sobhi 2006).

Furthermore, some heavy metals such as $\mathrm{Ag}, \mathrm{Al}, \mathrm{Cd}, \mathrm{Cr}, \mathrm{Hg}$, and $\mathrm{BP}$ have been traces in most stones. These elements fall in the group of non-essential or toxic trace elements because their biological significance is confined and the change is mainly due to environmental factors (Selvaraju et al 2006). In the present study, high concentrations of some elements ( $\mathrm{P}, \mathrm{Sr}, \mathrm{Mn}, \mathrm{Cu}$, and $\mathrm{Zn}$ ) have been recognized. Table 2 gives the comparison of the results obtained with the findings of other researches. The results showed that $\mathrm{Zn} \& \mathrm{Sr}$ contents have been higher when compared to others. It has been indicated that $\mathrm{Zn}$ is positively correlated with $\mathrm{Sr}$ and predominantly associated with apatite, which is substantiated by correlations established between $\mathrm{Zn}$ and $\mathrm{P}$ content of the stones (Wandt M. \& Underhill L. 1988). Low content of $\mathrm{Ca}$ as compared with that reported in literature for all stones may be attributed to the competition of $\mathrm{Sr}$ with $\mathrm{Ca}$ for apatite Lattice. $\mathrm{Sr}$ is so similar to $\mathrm{Ca}$ in its metabolism that is generally known to be a companion to the latter salts, $\mathrm{Sr}$ can exchange isomorphicaly with $\mathrm{Ca}$ in the lattice. The concentration of $\mathrm{Cu}$ has been found to be higher than in stones analysed in other correlation studies. $\mathrm{Cu}^{2+}$ ion can compete with $\mathrm{Ca}^{2+}$ in calcification. It was found that $\mathrm{Cu}^{2+} \& \mathrm{Zn}^{2+}$ have been present in gallstones and their presence could be explained as simple co-precipitation with cholesterol (Abu-Farsakh, F. 1997). All other trace metals in this study have played only a minor role in the chemical effects of mineral formation. This is because of the very low concentrations at which these metals have been present.

\section{Conclusion}

It is concluded that the origination of gallstones in woman are common but their formation and growth are different. Thirty fouthree heavy trace elements(Ag, Al, $\mathrm{As}, \mathrm{Ba}, \mathrm{Be}, \mathrm{Bi}, \mathrm{Ca}, \mathrm{Cd}, \mathrm{Co}, \mathrm{Cr}, \mathrm{Cu}, \mathrm{Fe}, \mathrm{Ga}, \mathrm{K}, \mathrm{La}, \mathrm{Mg}$, $\mathrm{Mn}, \mathrm{Mo}, \mathrm{Na}, \mathrm{Ni}, \mathrm{P}, \mathrm{Pb}$ in human gallstones were determined by ICP-AES analysis. Elemental comparison of their essential types of stones (cholesterol, pigment and mixed) shows that the amount of trace elements in pigment stones is higher than that in cholesterol or mixed stones. In general, the studied gallstones have low amount of $\mathrm{Ca}$.

\section{References}

A. Al - Sibaai, A. A. Kensara, and A. O. Baghlaf. (2006). El emental analysis as a strong tool for the determination of gallstones composition. JKAU:Sci., Vol.18,pp;33-45A.D./1427 A.H.).

Aboud,I.A. (2006). Mineralogy \& Chemistry of Urinary Stones-Patients from North Jordan-Study in Medical Geochemistry. Al al- Bayt University Projects.

Abu-Farsakh, F. (1997). Correlation between copper, zinc and some lipids in serum, bile and stones of patients with gallstone disease. Dirasat, Medical and Biological Sciences, 24 (1), 54-59.

Ashk M. Rautray, T. R., Pranaba, Narayana Kallkura K. Nayak, Vijayan V, Jeyanthi V, S. (2003). Energy dispersive X ray fluorescence analysis of gallstones. Journal of radio analytical and Nuclear Chemistry, 257(2)333-335(s).

A. Sahuquill, O, R. Rubio, J.M.Ribo, E. Ros., and M. Vela. (2000). Application of focused- microwave wet digestion to the determination of trace meatls in human gallstones by ICP/AES. J.Trace.Elem.Med.Biol., 14, 96-99.

Bianchi, F., Maffini, M., Mangia, A., Marengo, E., Mucchio, C. (2007). Experimental design optimization for the ICP-AES determination of $\mathrm{Li}, \mathrm{Na}, \mathrm{K}, \mathrm{Al}, \mathrm{Fe}, \mathrm{Mn}$ and $\mathrm{Zn}$ in human serum. Journal of Pharmaceutical and Biomedical Analysis.

Evenson, M. A, \& Warren, B. L. (1975). Determination of copper by atomic absorption, with use of the graphic cuvette. Clinical Chemistry, 21, 619-625.

Iyad Ahmed Abboud. (2007). Concentration effect of trace metals in Jordanian patients of urinary calculi. Journal of the Society for Environmental Geochemistry and Health, 3, 5-12.

J. Salimi, K. Moosavi, S. Vatankhah. (2003). The concentration of heavy terace elements in Pigment and Cholesterol Human gallstones: Comparative studies by PIXE analysis. Iran J. Radiat. Res., Vol 1 (2) 93-97.

Kafia, M. S. Slaiman, G. M. Nazanin, M. S. (2009). Physical and chemical states of drinking water from water treatment plants on greater zab river. J. Appl. Sci. Environ. Manage, vol. 13 (3) 89-92. 
Kafia, M. Shareef, Lazeeza,S.Omer, Sirwan, A. Garota. (2008). Predicting the chemical composition of Gallstones by FTIR spectroscopy. Biomedical \&Pharmacology Journal, (1) No.1, 25-30.

O. A. Golovanova, N. A. Palchik, N. Yu. Berezina, and L. N. Yudina. (2006). Comparative Characteristics of the Mineral and Microelement Composition of Gallstones Extracted from Patients in the Novosibirk and Omsk Regions, Chemistry for Sustainable Development, 14,125-131.

Pouls, M. \& Payne, M. (2006). Oral chelating and nutritional replacement therapy for heavy metal toxicity and cardiovascular conditions. Manuscript (written by Extreme Health), publishing by university of michgan.www.extremehealthusa.com.

Rautray, T. R., Vijayan, V., Panigrahi, S. (2006). Analysis of Indian cholesterol gallstones by particle-induced X-ray emission and thermogravimetry - derivative thermogravimetry. Eur. J. Gastron. Hepat, 18(9),999-1003.

R.Selvaraju,R.Ganapathi Raman, R. Narayan aswamy. (2006). Change in Serum Trace Elements Concentration before and after removal of Gallbladder with Gallstone. The Internet Journal of Gastroenterology. ISSN:1528-8323, 05 Nov 09. 13: 14, 06-0600

SSAT patient care guidelines. (2004). Treatment of gallstone and gallbladder disease. J Gastrointestinal Surg, 8:363-364

Sobhi. (2006). The mineralogy and chemistry of urinary stones from the Arabian Gulf. Internet site, work not published, Result work under proposing, pp. 8.

Wandt, M. A. E. \& Underhill, L. G. (1988). Covariance biplot analysis of trace element concentrations in urinary stone. British journal of Urology, 61, 474-481.

Xu Xiao Qing. (2002). Gallstones in potassium, magnesium, copper and zinc content by Atomic absorption spectrometry. Inner Mongolia Medical Journal, 06. 
Table 1. Types of gallstones and concentration of trace elements

\begin{tabular}{|c|c|c|c|c|c|c|}
\hline \multirow[t]{3}{*}{ Element } & \multicolumn{4}{|c|}{ Concentration(ppm) } & \multirow{2}{*}{\multicolumn{2}{|c|}{$\begin{array}{l}\text { Group } 3 \\
(\mathrm{n}=14)\end{array}$}} \\
\hline & $\begin{array}{l}\text { Group 1 } \\
(\mathrm{n}=13)\end{array}$ & & $\begin{array}{l}\text { Group } 2 \\
(\mathrm{n}=3)\end{array}$ & & & \\
\hline & Mean & Range & Mean & Range & Mean & Range \\
\hline $\mathrm{Ag}$ & $<0.4$ & $<0.2-1.0$ & 6.9 & $6.5-7.2$ & $<0.2$ & $<0.2-0.2$ \\
\hline $\mathrm{Al} \%$ & $<0.01$ & $<0.01-0.01$ & 0.01 & $<0.01-0.01$ & $<0.01$ & \\
\hline As & $<4$ & $<2-5$ & 4 & $3.56-4023$ & $<2$ & $<2-2$ \\
\hline $\mathrm{B}$ & $<10$ & & $<10$ & & $<10$ & \\
\hline $\mathrm{Ba}$ & $<10$ & & $<10$ & & $<10$ & \\
\hline $\mathrm{Be}$ & $<0.5$ & & $<0.5$ & & $<0.5$ & \\
\hline $\mathrm{Bi}$ & $<2$ & & $<2$ & & $<2$ & \\
\hline $\mathrm{Ca}$ & 0.082 & $<0.03-0.16$ & 11.55 & $11.3-11.7$ & 3.92 & $0.54-10.75$ \\
\hline $\mathrm{Cd}$ & $<0.5$ & & 0.9 & 085-1.05 & $<0.5$ & \\
\hline $\mathrm{Co}$ & $<1$ & & 1 & & $<1$ & \\
\hline $\mathrm{Cr}$ & 2.5 & $1-5$ & 1 & & $<1$ & $<1-5$ \\
\hline $\mathrm{Cu}$ & 21.5 & $2-89$ & 5150 & & 128.13 & $8-236$ \\
\hline $\mathrm{Fe} \%$ & 0.01 & $<0.01-0.01$ & 0.07 & & $<0.01$ & $<0.01-0.01$ \\
\hline $\mathrm{Ga}$ & $<10$ & & $<10$ & & $<10$ & \\
\hline $\mathrm{Hg}$ & $<1$ & & 1 & & $<10$ & \\
\hline $\mathrm{K} \%$ & $<0.01$ & & 0.07 & & 0.023 & $<0.01-0.05$ \\
\hline $\mathrm{La}$ & $<10$ & & $<10$ & & $<10$ & \\
\hline $\mathrm{Mg} \%$ & $<0.01$ & $<0.01-0.01$ & 0.2 & & 0.02 & 0.01-0.04 \\
\hline $\mathrm{Mn}$ & 2 & $<5-12$ & 1350 & & 114.75 & $16-274$ \\
\hline Mo & $<1$ & & $<1$ & & $<1$ & \\
\hline $\mathrm{Na} \%$ & 0.036 & $0.01-0.06$ & 1.12 & & 0.15 & $0.06-0.32$ \\
\hline $\mathrm{Ni}$ & $<1$ & & 2 & & $<1$ & $<1-2$ \\
\hline $\mathrm{P}$ & 146.67 & $30-560$ & $>10000$ & & 1115 & $750-2770$ \\
\hline $\mathrm{Pb}$ & $<2$ & & 43 & & 3.5 & $<2-5$ \\
\hline $\mathrm{S} \%$ & 0.01 & $<0.01-0.01$ & 0.96 & & 0.048 & $<2-5$ \\
\hline $\mathrm{Sb}$ & $<5$ & $<5-2$ & $<2$ & & $<2$ & \\
\hline $\mathrm{Sc}$ & $<1$ & & $<1$ & & $<1$ & \\
\hline $\mathrm{Sr}$ & 1 & $<1-2$ & 125 & & 33.625 & $2-169$ \\
\hline $\mathrm{Th}$ & $<20$ & & $<20$ & & $<20$ & \\
\hline $\mathrm{Tl}$ & $<10$ & & $<10$ & & $<10$ & \\
\hline $\mathrm{U}$ & $<10$ & & $<10$ & & $<10$ & \\
\hline $\mathrm{V}$ & $<1$ & & $<1$ & & $<1$ & \\
\hline $\mathrm{W}$ & $<10$ & & $<10$ & & $<10$ & \\
\hline $\mathrm{Zn}$ & $<2$ & & 224 & & 13.375 & $2-39$ \\
\hline
\end{tabular}


Table 2. Comparison of trace metals concentrations in gallstones from different studies

\begin{tabular}{|l|l|l|l|l|}
\hline \multicolumn{1}{|c|}{ Element } & \multicolumn{1}{|c|}{ Present study } & \multicolumn{1}{|c|}{$\operatorname{Iyad}(2007)$} & Al-Fawaaz(2006) & Jhaumeer-L\&Subratty(1999) \\
\hline $\mathrm{Na}$ & $0.00-0.3$ & $0.043-7.35$ & $1.27-9.12$ & $0.061-0.715$ \\
\hline $\mathrm{K}$ & $0.00-0.07$ & $0.002-1.57$ & $0.19-3.02$ & $0.03-0.56$ \\
\hline $\mathrm{Ca}$ & $0.03-17.5$ & $6.8-38.25$ & $24.7-88.8$ & $0.16-32.81$ \\
\hline $\mathrm{Mg}$ & $0.00-0.2$ & $0.009-6.95$ & $0.39-2.83$ & $0.0004-4.6$ \\
\hline $\mathrm{Fe}$ & $0.00-0.07$ & $0.09-3.85$ & $0.17-2.05$ & $0.00095-5.23$ \\
\hline $\mathrm{Al}$ & $0.00-0.01$ & $0.006-0.96$ & $1.15-11.5$ & - \\
\hline $\mathrm{Zn}$ & $2-224$ & $0.005-1.56$ & $0.1-.58$ & $0.002-0.799$ \\
\hline $\mathrm{Cu}$ & $2-5150$ & $0.002-1.05$ & $0.24-0.33$ & $4.5 \times 10^{-5}-0.0059$ \\
\hline $\mathrm{Mn}$ & $5-1350$ & $0.005-0.06$ & - & \\
\hline $\mathrm{P}$ & $30-10000$ & $0.55-29.65$ & $1.05-7.38$ & $1-67.6$ \\
\hline $\mathrm{S}$ & $0.01-0.9$ & $0.32-8.36$ & $0.29-4091$ & - \\
\hline $\mathrm{Sr}$ & $1-169$ & $0.006-0.88$ & $0.06-0.16$ & - \\
\hline $\mathrm{Mo}$ & $0.00-1.0$ & $0.005-0.91$ & $1.7-17.47$ & - \\
\hline $\mathrm{Cr}$ & $0.00-1.00$ & $0.003-0.77$ & - & $0.0015-0.017$ \\
\hline $\mathrm{Co}$ & $0.001-1$ & $0.001-0.08$ & $0.9-11.0$ & \\
\hline $\mathrm{Ni}$ & $0.00-2$ & $0.008-0.03$ & $0.43-1.34$ & - \\
\hline
\end{tabular}

